\title{
THE EFFECT OF 5-AMINOSALICYLIC ACID ON INTESTINAL MICROBIOTA
}

\author{
Vanda Sargautiene ${ }^{1}$, Renāte Ligere ${ }^{1}$, Ineta Kalniṇa ${ }^{2}$, Ida Jākobsone ${ }^{3}$, \\ Vizma Nikolajeva ${ }^{4}$, and Aleksejs Derovs ${ }^{5,6}$ \\ ${ }^{1}$ Department of Internal Medicine, University of Latvia, 3 Jelgavas Str., Rīga, LV-1004, LATVIA \\ ${ }^{2}$ Latvian Biomedical Research and Study Centre, 1 Rātsupītes Str., Rīga, LV-1067, LATVIA \\ ${ }^{3}$ Department of Organic Chemistry, University of Latvia, 1 Jelgavas Str., Rīga, LV-1004, LATVIA \\ ${ }^{4}$ Department of Microbiology and Biotechnology, University of Latvia, 1 Jelgavas Str., Rīga, LV-1004, LATVIA \\ ${ }^{5}$ Gastroenterology, Hepatology and Nutrition Clinic, Rīga East Clinical University Hospital, 2 Hipokrāta Str., Rīga, LV-1038, LATVIA \\ ${ }^{6}$ Department of Internal Diseases, Rīga Stradinš University, 16 Dzirciema Str., Rīga, LV-1007, LATVIA \\ Corresponding author: vandasarg@outlook.com
}

Communicated by Aigars Pētersons

\begin{abstract}
The article discusses the possible relationships between intestinal microbiota and the therapeutic efficacy of 5-aminosalicylic acid (5-ASA) in inflammatory bowel diseases. Intestinal microbiota may be involved in 5-ASA enzymatic biotransformation, but the metabolism of drugs by the intestinal microbiota has been studied in less detail, and little is known about the relationships between anti-inflammatory efficacy of 5-ASA with bacterial viability, quantity and activity. It remains unclear whether 5-ASA affects the microbiota depending on the different segments of gastrointestinal tract. Drugs and diet can both improve and worsen the composition of the intestinal microbiota. However, it is not known whether drugs affect the intestinal microbiota regardless of diet. Further research is needed to answer these questions.
\end{abstract}

Key words: 5-ASA, inflammatory bowel diseases, microbiota, inflammation.

\section{INTRODUCTION}

Inflammatory bowel disease (IBD) is an idiopathic disease and consists of two major disorders: ulcerative colitis (UC) limited to the colon, and Crohn's disease (CD), which is able to affect any segment of the gastrointestinal tract (Perrotta, 2015). IBD predicts health-related quality of life and work-related outcomes (Farzaneh et al., 2017) leading to reduced working capacity and significant socio-economic consequences (Jean et al., 2018).

Chronic intestinal inflammation is the primary risk factor for the development of gastrointestinal malignancy, including colorectal cancer (CRC) (Axelrad, 2016); therefore, anti-inflammatory treatment in IBD should be considered.

5-Aminosalicylic acid (5-ASA) (also mesalamine or mesalazine) is an anti-inflammatory medicine used to control mild inflammation and symptoms in patients with IBD (Perrotta, 2015), most often used to treat UC (Ham, 2012;
Ye, 2015). Studies have demonstrated that 5-ASA prevents the development of CRC in patients with long-standing colitis and inhibits tumour growth in colon cancer patients (Ikeda, 2007; Rubin, 2008; 2014; Zhang, 2018).

The main anti-inflammatory mechanism of 5-ASA includes inhibition of cyclooxygenase and lipoxygenase, subsequently leading to reduced production of prostaglandins and leukotrienes (Kaiser, 1999; Baumbart, 2012; Berends, 2019).

5-ASA has been shown to be effective when used as either an oral therapy, a rectal therapy administered as a suspension, suppository, gel or foam, or when oral and rectal formulations are used in combination. Various oral formulations have been developed in an attempt to optimise drug delivery to the region of active disease; each differs in terms of enteric coating, site of drug release and mode of drug delivery (Ye, 2015). 
About $30 \%$ of the 5-ASA is absorbed rapidly in the small intestine, metabolised locally and by the liver to N-Ac-5ASA (an inactive metabolite) by $\mathrm{N}$-acetyltransferase 1 (NAT 1) present in intestinal epithelial cells and liver (Ham, 2012). It is then excreted in the urine as free 5-ASA and NAc-5-ASA or excreted unabsorbed with faeces (Berends, 2019).

Medicines administered rectally and those not absorbed or incompletely absorbed in the upper gut following oral administration, may be subjected to biotransformation to active/inactive metabolite(s) by the colonic microbiota (Kim, 2015: Abdu-Allah et al., 2016); some bacterial N-acetyltransferases might be involved in the metabolism of 5-ASA (Deloménie, 2001).

5-ASA is metabolised by $\mathrm{N}$-acetyltransferase (NAT) enzymes, which catalyse the transfer of an acetyl moiety from acetyl-coenzyme A (AcCoA) to the nitrogen ( $\mathrm{N}$-acetylation) of the 5-ASA to form the metabolite N-acetyl-5-ASA (Raminez-Alcantara, 2014).

Bacterial NAT activities have features similar to those of the human NAT1 and NAT2 isoenzymes (Deloménie, 2001). N-acetyltransferase activity was reported in 11 species of Proteobacteriaceae from seven genera; Pseudomonas aeruginosa was seen to be the most efficient at performing this reaction (Deloménie, 2001; Wilson, 2017). It has been shown that 5-ASA was acetylated with a catalytic efficiency 27 to 645 times higher than that of its isomer 4ASA (Deloménie, 2001).

It is not known whether effectiveness of 5-ASA therapy depends on the viability and effectiveness of the enzymatic biodegradation of 5-ASA by intestinal microbiota.

5-ASA might affect the intestinal microbiota of patients with IBD in different ways, depending on the different routes of administration (oral or rectal). As far as we know no comparative studies have been published previously on the possible biodegradation of 5-ASA by bacteria in different routes of administration (oral vs rectal), and how this affects the viability of beneficial bacteria.

\section{THE ANTI-INFLAMMATORY EFFECT OF 5-ASA AND ITS EFFECT ON INTESTINAL MICROBIOTA}

The main goal of the various 5-ASA formulations currently available on the market is to optimise drug delivery to the affected colon and minimise systemic absorption (Ye, 2015). However, about $30 \%$ of patients treated with 5-ASA are considered not responders, because of allergy, intolerance, underdosage, refractoriness to the treatment, and the need of switching their therapy to more potent and toxic medications (Perrotta, 2015).

It is unknown whether the anti-inflammatory effectiveness of the 5-ASA depends on intestinal bacteria viability, quantity and activity. It is also not clear whether it affects di- rectly the intestinal microbiota, after the active substance enters the colon.

5-ASA treatment was associated with a decrease in faecal bacteria abundance and rebalancing of the major constituents of the microbiota (Andrews, 2011). Recent results reveal a multifaceted and previously unrecognised effect of 5-ASA on the growth and virulence of E. coli; in a dosedependent manner it reduced the expression of bacterial virulence genes associated with IBD (Zhang, 2018).

The interaction of 5-ASA therapy with pathogenic bacteria (their viability and activity) has been studied in less detailed, and it is not known whether this is related to the effectiveness of 5-ASA.

It was found that after 5-ASA treatment, the abundance of Firmicutes significantly increased, and the abundance of Bacteroidetes significantly decreased in inflamed mucosae (Xu et al., 2018). It is interesting that the abundance of several bacteria such as Faecalibacterium prausnitzii and Akkermansia muciniphila also decreased after 5-ASA treatment (Xu et al., 2018). However, it is not clear whether 5ASA has a direct effect on viability of bacteria, or indirect, such as change in $\mathrm{pH}$, inhibition by other bacteria etc.

It was suggested that 5-ASA is released in the colon and translated into acetylsalicylic acid, which may reduce the luminal $\mathrm{pH}$ and bacterial diversity (Xu et al., 2018). Different strains of microbiota colonise in different segments of the gastrointestinal (GI) tract. A. muciniphila prefers the distal colon environment due to its higher $\mathrm{pH}$ (Herreweghek, 2017). We suggest that suppository 5-ASA may increase the acidity of the distal colon (lower $\mathrm{pH}$ ), and this may have inverse effect on $A$. mисіniphila viability.

A more recent study highlights a novel aspect of the interaction between the gut microbiota and host's intestinal homeostasis, highlighting that the anti-inflammatory effect of the gut microbiota is mediated, in part, by A. muciniphila, which helps to regulate mucin, a major component of the mucous layer that resides on the surface on the gastrointestinal mucosa and helps to protect intestinal health (Bland, 2016). Mucosal healing is an important outcome, and may prevent or reduce the risk of colorectal cancer in IBD (Probert, 2014). A. muciniphila represents between 1 to $3 \%$ of the gut microbiota, and a decrease of relative amount of this species has been demonstrated in faeces and/or biopsies of several disorders including IBD (Lopez-Siles, 2018).

The abundance of $A$. muciniphila in the gut microbiota is inversely correlated with IBD (Chia et al., 2018). Mucin degradation by A. muciniphila yields short chain fatty acids (SCFA) and mucin-derived monosaccharides, which support the growth and concomitant butyrate production of non-mucolytic butyrogens (Belzer et al., 2017).

Studies have shown a relationship between intestinal microbiota and the pathogenesis of inflammatory processes in the intestine (Sasaki and Klapproth, 2012) associated with a decrease in the production of the butyrate by bacteria 
(Sasaki and Klapproth, 2012) (van der Beek et al., 2017) (Machiels et al., 2014). Butyrate exerts anti-inflammatory effects in intestinal mucosa by inhibition of histone deacetylases (HDACs) and activation of the G-protein-coupled receptors (GPCRs) present in intestinal epithelial cells (IECs) and immune cells. In IECs models, butyrate suppresses lipopolysaccharide (LPS)-induced NF- $\kappa \mathrm{B}$ activation via GPR109A in vitro in colonic cell lines and ex vivo in mouse colon (Thangaraju, 2009; Parada,2019).

F. prausnitzii, affiliated with the family Ruminococcaceae, is a butyrate producer and an anti-inflammatory bacterium with therapeutic potential for patients with IBDs, $F$. prausnitzii can be present in proportions of between 2 to $15 \%$ (Lopez-Siles et al., 2018). It was reported that quantity of $F$. prausnitzii is reduced under IBD conditions (Machiels, 2014; Parada, 2019) and as mentioned above, it decreases after 5-ASA treatment (Xu et al., 2018). The question arises, what exactly affects $F$. prausnitzii.

Western style diets, low in dietary fibre, high in sugar and fats, trigger IBD disease outbreak and loss of important short chain fatty acids (SCFA) producing microbes (Laffin, 2019). SCFA are microbial metabolites, one of which is the above mentioned butyric acid, is the main source of energy for the colon's epithelial cells, which can inhibit development of colorectal cancer (CRC) and promote intestinal health (Xinqiang et al., 2018). Butyrate plays beneficial roles in anti-inflammation, anti-carcinogenesis, mucosal protection and healing processes (van der Beek et al., 2017).

It is well-known fact that dietary fibres are directly linked to an increase in the beneficial bacteria and the production of butyric acid (Cuervo, 2013). However, less is known of whether the type of diet can affect the microbiota when medicines are used.

Based on the foregoing, it is clear that medicines can affect the composition of the microbiota; they apparently can also affect the quantity of metabolites produced by bacteria, such as SCFAs, including butyric acid. Further questions arise regarding biotransformation of 5-ASA by gut microbiota using different routes of administration and its further effect on anti-inflammatory efficacy of the medicines and beneficial bacteria viability and productivity.

\section{SUGGESTED STEPS FOR DETERMINING THE EF- FECT OF THE 5-ASA ON THE INTESTINAL MICROBI- OTA}

Since various factors (medications, diet, stress, lifestyle, etc.) can affect the intestinal microbiota, determining the effect of medicines on the intestinal microbiota can be complicated.

We suggest some steps to analyse this effect; however, to obtain more accurate data, all of them should preferably be performed.
First, the bacterial potential for 5-ASA acetylation should be carried out in pure cultures of the bacteria concerned. Pure cultures of microorganisms should be cultivated based on the manufacturer's instructions in broth with the presence or absence of different concentrations of 5-ASA.

Second, native microbiota (patient stool suspension) prior to the administration of 5-ASA can be used to study the personalised effect of 5-ASA acetylation and its effect on viability and efficacy of bacteria in vitro.

Finally, the bacterial diversity (in the bacterial phylum and genus level) of stool samples can be compared by analysing the composition of intestinal microbiota before and after prescribing medications using next-generation sequencing (NGS), 16S rRNA gene sequencing methods. Additionally, gut microbiome profiling might be carried out by shotgun metagenome sequencing complemented by targeted quantification of interesting bacteria by quantitative PCR (qPCR), which gives more accurate estimates of actual abundance compared to calculations of relative abundances from whole metagenome samples.

The concentration of bacterial metabolites, such as SCFA, $\mathrm{N}$-acetyl-5ASA (metabolite of 5-ASA), can be analysed using chromatography, which allows to use existing methods previously described in the scientific literature, and/or optimise the method that will be used for determination of bacterial metabolites. Of course, to ensure reproducibility of the study series, the sensitivity, linearity range, repeatability and robustness of the method should be determined.

\section{CONCLUSIONS AND FURTHER PROSPECTS}

5-aminosalicylic acid (5-ASA) is used to treat IBD. The exact pharmacological mechanism of 5-ASA is not precisely known, although a local anti-inflammatory effect is considered.

The effect of bacteria on the biodegradation of 5-ASA in different routes of administration of medicines (oral or rectal), and the further impact on viability and efficacy of gut beneficial bacteria are not fully understood and, as far as we know, have not been compared previously.

Characterisation of the microbial pathways involved in colonic 5-ASA metabolism is necessary for a better understanding of its contribution to colonic dysbiosis.

Development of therapeutic strategies and new approaches of the interaction between bacteria and medicines should be explored for more effective treatment of IBD by maintaining and promoting viability and effectiveness of beneficial bacteria.

\section{REFERENCES}

Abdu-Allah, H., El-Shorbagi, A., Abdel-Moty, S., El-Awady, R., Abdel-Alim, A. (2016). 5-Aminosalicylic acid (5-ASA): A unique anti-inflammatory salicylate. Med. Chem., 6 (5), 306-315. 
Andrews, C. G. (2011). Mesalazine (5-aminosalicylic acid) alters faecal bacterial profiles, but not mucosal proteolytic activity in diarrhoea-predominant irritable bowel syndrome. Aliment. Pharmacol. Ther., 34 (3), 374-383.

Axelrad, J. L. (2016). Inflammatory bowel disease and cancer: The role of inflammation, immunosuppression, and cancer treatment. World J. Gastroenterol., 22 (20), 28.

Baumgart, D. (2012). Crohn's Disease and Ulcerative Colitis: From Epidemiology and Immunobiology to a Rational Diagnostic and Therapeutic Approach. Springer Science \& Business Media. 695 pp.

Belzer, C., Chia, L., Aalvink, S., Chamlagain, B., Piironen, V., Knol, J., de Vos, W. (2017). Microbial metabolic networks at the mucus layer lead to diet-independent butyrate and vitamin B12 production by intestinal symbionts. MBio, 8 (5).

Berends, S. S. (2019). Clinical pharmacokinetic and pharmacodynamic considerations in the treatment of ulcerative colitis. Clin. Pharmacokinet., $\mathbf{5 8}$ (1), 15-37.

Bland, J. (2016). Intestinal microbiome, Akkermansia muciniphila, and medical nutrition therapy. Integr. Med. (Encinitas), 15 (5), 14-16.

Chia, L. W., Knol, J., Belzer, C. (2018). Deciphering the trophic interaction between Akkermansia muciniphila and the butyrogenic gut commensal Anaerostipes caccae using a metatranscriptomic approach. Antonie Van Leeuwenhoek, 111 (6), 859-873.

Cuervo, A. S.-M. (2013). Fiber from a regular diet is directly associated with fecal short-chain fatty acid concentrations in the elderly. Nutr. Res., 33 (10), 811-816.

Deloménie, C. F. (2001). Identification and functional characterization of arylamine $\mathrm{N}$-acetyltransferases in eubacteria: Evidence for highly selective acetylation of 5-aminosalicylic acid. J. Bacteriol., 183 (11), 3417-3427.

Farzaneh, H., Mohammad, E. H., Gharavinia, A., Mahdavi, S. B., Akbarpour, M. J., Baghaei, A., Emami., M. H. (2017). Quality of life in inflammatory bowel disease patients: A cross-sectional study. J. Res. Med. Sci., 22, 104.

Gobert, A. P., Sagrestani, G., Wilson, E. D., Verriere, T. G., Dapoigny, M., Del'homme, C., Bernalier-Donadille, A. (2016). The human intestinal microbiota of constipated-predominant irritable bowel syndrome patients exhibits anti-inflammatory properties. Sci. Rep., 6, Article No. 39399.

Ham, M. M. (2012). Mesalamine in the treatment and maintenance of remission of ulcerative colitis. Expert Rev. Clin. Pharmacol., 5 (2), 113-123.

Herreweghen, F. A.-S.-V. (2017). In vitro colonisation of the distal colon by Akkermansia muciniphila is largely mucin and $\mathrm{pH}$ dependent. Beneficial Microbes, 8 (1), 81-96.

Ikeda, I. T. (2007). 5-aminosalicylic acid given in the remission stage of colitis suppresses colitis-associated cancer in a mouse colitis model. Clin. Cancer Res., 13 (21), 6527-6531.

Ye, B. (2015). Mesalazine preparations for the treatment of ulcerative colitis: Are all created equal? World J. Gastrointest. Pharmacol. Ther., 6 (4), $137-144$.

Jean, L., Audrey, M., Beauchemin, C., Consrtium, O. (2018). Economic evaluations of treatments for inflammatory bowel diseases: A literature review. Can. J. Gastroenterol. Hepatol., 2018, 7439730.

Kaiser, G. Y. (1999). Mesalamine blocks tumor necrosis factor growth inhibition and nuclear factor kappaB activation in mouse colonocytes. Gastroenterology, 116 (3), 602-609.

Kim, D. (2015). Gut microbiota-mediated drug-antibiotic interactions. Drug Metab. Dispos., 43 (10), 1581-1589.

Laffin, M. F. (2019). A high-sugar diet rapidly enhances susceptibility to colitis via depletion of luminal short-chain fatty acids in mice. Sci. Rep., 9, 12294.

Lopez-Siles, M., Enrich-Capó, N., Aldegue, X., Sabat-Mir, M., Duncan, S., Garcia-Gil, L., Martinez-Medina, M. (2018). Alterations in the abundance

Received 29 January 2020

Accepted in the final form 25 February 2020 and co-occurrence of Akkermansia muciniphila and Faecalibacterium prausnitzii in the colonic mucosa of inflammatory bowel disease subjects. Front Cell Infect. Microbiol., 7 (8), 281.

Machiels, K. J., Arijs, I., Eeckhaut, V. V., Verbeke, K., Ferrante, M. V. (2014). A decrease of the butyrate-producing species Roseburia hominis and Faecalibacterium prausnitzii defines dysbiosis in patients with ulcerative colitis. Gut, 63 (8), 1275-1283.

Martín, R. C.-H. (2014). The commensal bacterium Faecalibacterium prausnitzii is protective in DNBS-induced chronic moderate and severe colitis models. Inflamm. Bowel Dis., 20 (3), 417-430.

Parada, V. D. (2019). Short chain fatty acids (SCFAs)-mediated gut epithelial and immune regulation and its relevance for inflammatory bowel diseases. Front Immunol., 10, 277

Perrotta, C. P. (2015). Five-aminosalicylic acid: An update for the reappraisal of an old drug. Gastroenterol. Res. Pract., 2015, 456895, 1-9.

Probert, C. D. (2014). Combined oral and rectal mesalazine for the treatment of mild-to-moderately active ulcerative colitis: Rapid symptom resolution and improvements in quality of life. J. Crohn's Colitis, 8 (3), 200-207.

Ramirez-Alcantara, V. M. (2014). Acute murine colitis reduces colonic 5-aminosalicylic acid metabolism by regulation of $\mathrm{N}$-acetyltransferase-2. Amer. J. Physiol. Gastrointest. Liver Physiol., 306 (G), 1002-1010.

Rubin, D. (2014). Why it's time for updated U.S. colorectal cancer prevention guidelines in inflammatory bowel disease. Gastrointest. Endosc., 80 (5), 849-851.

Rubin, D. C. (2008). Colorectal cancer prevention in inflammatory bowel disease and the role of 5-aminosalicylic acid: A clinical review and update. Inflamm. Bowel Dis., 14 (2), 265-274.

Sartor, R. W. (2017). Roles for intestinal bacteria, viruses, and fungi in pathogenesis of inflammatory bowel diseases and therapeutic approaches. Gastroeterology., 155 (2), 327-339.

Sasaki, M., Klapproth, J. (2012). The role of bacteria in the pathogenesis of ulcerative colitis. J. Signal Transduct., 2012, 704953

Sheehan, D. S. (2017). The gut microbiota in inflammatory bowel disease. Gastroenterol. Clin. North Amer., 46, 143-154.

Sonu, I. L. (2010). Clinical pharmacology of 5-ASA compounds in inflammatory bowel disease. Gastroenterol. Clin. North. Amer., 39 (3), 559-599.

Thangaraju, M. C. (2009). GPR109A is a g-protein-coupled receptor for the bacterial fermentation product butyrate and functions as a tumor suppressor in colon. Cancer Res., 69, 2826-2832.

van der Beek, C., Dejong, C., Troost, F., Masclee, A., Lenaerts, K. (2017) Role of short-chain fatty acids in colonic inflammation, carcinogenesis, and mucosal protection and healing. Nutr. Rev., 75 (4), 286-305.

Wilson, I. N. (2017). Gut microbiome interactions with drug metabolism, efficacy and toxicity. Transl. Res., 179, 204-222.

Xinqiang, W., Yuanbing, W., Liangmei, H., Longhuo, W., Xiangcai, W., Zhiping, L. (2018). Effects of the intestinal microbial metabolite butyrate on the development of colorectal cancer. J. Cancer., 9 (14), 2510-2517.

Xu, J., Chen, N., Wu, Z., Song, Y., Zhang, Y., Wu, N., Zhang, F., Ren, X., Liu, Y. (2018). 5-Aminosalicylic acid alters the gut bacterial microbiota in patients with ulcerative colitis. Frontiers Microbiol., 9, 1274.

Xue, L. H. (2012). The possible effects of mesalazine on the intestinal microbiota. Aliment. Pharmacol. Ther., 36, 811-814.

Xue, L., Huang, Z., Chen, X. Z. (2012). The possible effects of mesalazine on the intestinal microbiota. Aliment. Pharmacol. Ther., 36, 811-814.

Zhang, S. F. (2018). 5-Aminosalicylic acid downregulates the growth and virulence of Escherichia coli associated with IBD and colorectal cancer, and upregulates host anti-inflammatory activity. J. Antibiot. (Tokyo), 71 (11), 950-961. 


\section{5-AMINOSALICILSKĀBES IETEKME UZ ZARNU MIKROBIOTU}

Rakstā apskatītas iespējamās saistības starp zarnu mikrobiotu un 5-aminosalicilskābes (5-ASA) terapeitisko efektivitāti iekaisīgo zarnu slimību gadījumā. Zarnu mikrobiota var būt iesaistīta 5-ASA fermentatīvā biotransformācijā. Zāḷu metabolisms ar zarnu mikrobiotu ir pētīts mazāk detalizēti, maz ir zināms, vai 5-ASA pretiekaisuma iedarbība korelē ar baktēriju dzīvotspēju, daudzumu un aktivitāti. Joprojām nav skaidrs, vai 5-ASA ietekmē mikrobiotu atkarībā no dažādiem kuṇǵa un zarnu trakta segmentiem. Zāles un diēta var gan uzlabot, gan pasliktināt zarnu mikrobiotas sastāvu. Tomēr nav zināms, vai zāles neatkarīgi no uztura ietekmē zarnu trakta mikrobiotu. 